Primljen / Received: 18.9.2013. Ispravljen / Corrected: 29.11.2013.

Prihvaćen / Accepted: 27.12.2013. Dostupno online / Available online: 10.1.2014.

\section{Regression modelling of traffic noise pollution}

\title{
Authors:
}

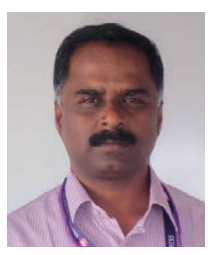

Yugananth Pachiappan, Research Scholar Anna University

Chennai, TamilNadu, India

yugananthtnp@gmail.com

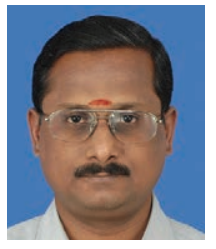

Assoc.Prof. Baskar Govindaraj, PhD. CE Institute of Road and Transport Technology Department of Civil Engineering Erode, TamilNadu, India baskar@irttech.ac.in

\section{Yugananth Pachiappan, Baskar Govindaraj}

\section{Regression modelling of traffic noise pollution}

Noise is distinctive in comparison to pollutants like air, water and soil. It does not leave any residual evidence that would serve as a continuing reminder of its unpleasantness. Models like FHWA, CORTN, STOP and GO are used for traffic noise prediction in the US, UK, and Bangkok, respectively. But so far, no definite model has been developed for Indian road conditions. A new road traffic noise prediction model for uninterrupted four-lane Indian roads, developed using the regression analysis, is presented in this paper. This model can be effectively used as a decision-supporting tool for road traffic noise prediction on Indian roads.

Key words:

transport, traffic noise, mathematical modelling, noise emission

Yugananth Pachiappan, Baskar Govindaraj

Prethodno priopćenje

\section{Regresijsko modeliranje onečiščenja prometnom bukom}

Buka se razlikuje od pojava koje dovode do onečišćenja zraka, vode i tla jer ne ostavlja nikakav trag koji bi poslužio kao stalni podsjetnik na neugodu koju uzrokuje. U SAD-u, Velikoj Britaniji i Bangkoku koriste se modeli kao što su FHWA, CORTN, STOP i GO. Međutim, do sada nije razvijen konačan model za indijske uvjete cestovnog prometa. U ovom se radu prikazuje novi model za predvidanje prometne buke zbog neprekinutog odvijanja cestovnog prometa po četverotračnim cestovnim prometnicama u Indiji. Ovaj model, utemeljen na regresijskoj analizi, može se djelotvorno koristiti kao podrška pri donošenju odluka o predvidanju prometne buke na indijskim cestama.

Ključne riječi:

promet, prometna buka, matematičko modeliranje, emisija buke

Vorherige Mitteilung

Yugananth Pachiappan, Baskar Govindaraj

\section{Regressionsmodellierung von Verkehrslärm}

Lärm ist spezifisch im Vergleich zu anderen Verschmutzungen von Luft, Wasser und Boden, da er keine verbleibenden Rückstände hinterlässt, die kontinuierlich an seine Unannehmlichkeit erinnern. Modele wie z.B. FHWA, CORTN, STOP und GO werden für die Vorhersage von Verkehrslärm in den USA, Großbritannien und Bangkok angewandt. Bisher ist kein bestimmtes Vorhersagemodel für Indische Straßenbedingungen entwickelt worden. In dieser Arbeit wird ein neues, auf der Regressionsanalyse beruhendes Model zur Lärmvorhersage für ununterbrochene Vierspurstraßen in Indien vorgeschlagen, das als effektives Instrument zur Entscheidungsunterstützung in Verkehrslärmvorhersagen für Indische Straßen angewandt werden kann. 


\section{Introduction}

A highway network is the most important part of a country's economy which acts like nerves in a human body. India has more than 4.32 million kilometres of roads in its highway network. This is the second largest highway network in the world, second only to the United States which has about 7.0 million kilometres of roads. Indian roads carry about $65 \%$ of freight traffic and $35 \%$ of passenger traffic, with the vehicle population growth rate of about $12 \%$. Also, the road traffic is increasing at the rate of about $10 \%$, compared to the standard growth rate of $7.5 \%$. Such a rapid increase in the number of vehicles in India requires development of its highway network, which leads to infrastructure development, industrialization, and urbanization. Such developments result in crowded roads and various kinds of pollution. Air pollution, road traffic injuries, climate change, and noise pollution, are the major problems associated with transport development. Among these problems, noise pollution is the least considered and unattended issue, largely neglected by the majority of engineers, planners and politicians in most countries. Noise is unique in comparison with other pollutants because, unlike air, water or soil pollution, it does not have any residual evidence that would serve as a continuing reminder of its unpleasantness.

An inappropriate level of noise affects physical and psychological characteristics of persons exposed to this kind of pollution. Depending on its duration and volume of exposure, the effects of noise on human health and comfort can be divided into four categories; physical effects, such as hearing defects; physiological effects, such as high blood pressure, irregularity of heart rhythm, and ulcers; psychological effects, such as disorders, sleeplessness and going to sleep late, irritability and stress; and, finally, effects on work performance, such as reduction of productivity and misunderstanding what is heard [1].

Ambient noise standards applied in India for industrial, commercial, residential and silence areas, during the day and during nighttime, as per the Central Pollution Control Board Government of India, are given in Table 1.

Table 1. Ambient Noise Standards in India

\begin{tabular}{|c|c|c|}
\hline \multirow{2}{*}{ Area } & \multicolumn{2}{|c|}{ Limits in dB(A) } \\
\cline { 2 - 3 } & $\begin{array}{c}\text { Day time } \\
(\mathbf{0 6 : 0 0}-\mathbf{2 2 : 0 0 )}\end{array}$ & $\begin{array}{c}\text { Night time } \\
(\mathbf{2 2 : 0 0}-\mathbf{0 6}: 00)\end{array}$ \\
\hline 1. Industrial area & 75 & 70 \\
\hline 2. Commercial area & 65 & 55 \\
\hline 3. Residential area & 55 & 45 \\
\hline 4. Silence zone & 50 & 40 \\
\hline
\end{tabular}

Traffic noise along highways can be either measured or predicted. Noise measurements are complicated and time consuming. In addition to that, noise can not be measured at the design stage [2]. When designing new highways, traffic noise prediction models are required in order to provide for a comfortable living environment in industrial, commercial, residential and silence areas. Furthermore, the analysis and modelling of traffic noise facilitates proper planning of environmentally friendly roads [3]. Appropriate prediction models can be used to develop various noise-control techniques before construction, and to incorporate most effective control measures in the design. These procedures make it unnecessary to respond to complaints from people living in the vicinity of highways after their construction, and alleviate the need to minimize high-cost post-construction protection measures. Prevention is always better than the cure [4]. In general, sound level has a lot of variations. Taking into account human ear's response to different levels of sound, weighting filters are used to measure sound levels. The A-weighted sound level is formulated in order to characterize more accurately the response of humans to the variation of sound. This $A$ weighted sound-level measurement in decibels, expressed as $d B(A)$, is a commonly accepted scale for measuring sound levels in transport sector [5].

Noise levels generated by vehicles along highways are extremely variable over time. In order to simplify this issue, a universally used parameter Leq, the energy equivalent noise level, has been derived to obtain a meaningful statistical average noise level that describes the same magnitude of noise exposure during the measuring period. So, the Leq can substitute varying noise levels with a single noise level value, which is expressed in $\mathrm{dB}(\mathrm{A})[6]$. Hence, an attempt has been made to predict the equivalent level of noise for the four-lane uninterrupted traffic flow along the Salem-Cochin road $(\mathrm{NH}$ 47) in Tamil Nadu, India.

\section{Objectives of this study}

Main objectives of this study are:

a) To measure the prevailing noise level due to vehicle flow in the study area.

b) To develop a multiple linear regression model for prediction of traffic noise.

c) To check the goodness of fit of the proposed model.

d) To develop equations of individual vehicle noise by each category of vehicles based on its spot speed.

e) To carry out a correlation study of noise pollution with various traffic flow and road parameters.

\section{Materials and methodology}

\subsection{Study area}

The Salem - Cochin road is an important National Highway (NH 47) with a heavy traffic flow, which connects Tamil Nadu and Kerala states in India. It is a four lane road with 
a $4.5 \mathrm{~m}$ wide median. In this study, traffic noise and other parameters are measured on a straight road stretch, with an uninterrupted traffic flow, and without any junctions, structures or cross drainage structures like culverts and bridges within $500 \mathrm{~m}$ distance on both sides. Four locations satisfying these criteria, i.e. $\mathrm{km} 82 / 2, \mathrm{~km} \mathrm{73/10,} \mathrm{km} \mathrm{68/8,}$ and $\mathrm{km} \mathrm{60/10,} \mathrm{are} \mathrm{considered} \mathrm{for} \mathrm{taking} \mathrm{measurements} \mathrm{in}$ this study to develop the model. An another location on the

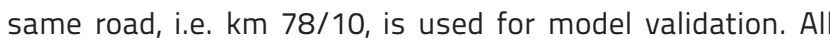
these locations are characterized by a high quality flexible pavement with good riding surface. These road stretches are shown on the location map given in Figure 1. All data were obtained under favourable meteorological conditions, that is, in the absence of wind and rain.

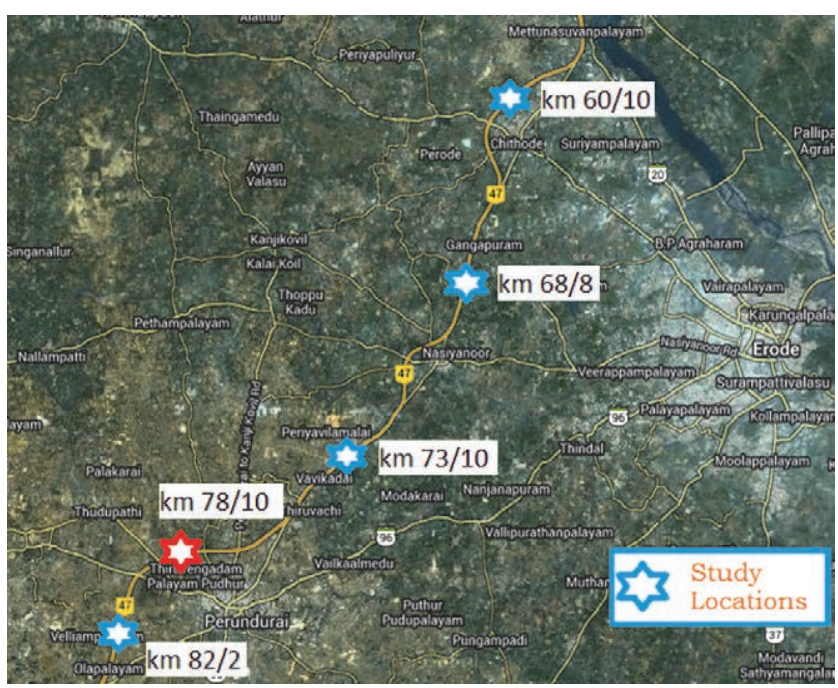

Figure 1. Location map showing the study locations on $\mathrm{NH}-47$

\subsection{Study period}

All data were collected between 06:00 hours and 19:00 hours. The behaviour of vehicles and drivers might vary depending on the direction of travel. Hence, in order to obtain accurate data, the measurements were taken on both sides of the road for every hour. For developing model, the data were collected at 4 locations, during 2 hours at each location. In each hour, the measurements were taken on both left and right sides of the road.

The first set of readings was taken on the left side of the road during the first 20 minutes, which was followed by a 10 minute interval in which the instruments were moved from the left side to the right side of the road. The next set of readings was taken on the right side of the road during the next 20 minutes. This was also followed by a 10 minute interval for shifting the instruments from the right side to the left side, The same procedure was conducted for the next hour.

Hence, every particular location had 4 sets of readings ( 2 sets of readings on the left side and 2 sets of readings on the right side). In total, 16 sets of readings were made on 4 locations. The remaining time was used for moving and fixing the instruments, furniture etc. in proper position at the specified location.

\subsection{Field studies}

In view of the objectives, a field data collection program was designed to collect the following parameters.

a) Traffic volume,

b) Spot speed of each category of vehicle,

c) Noise level,

d) Atmospheric temperature,

e) Pavement surface temperature,

f) Relative humidity.

\subsection{Traffic volume count}

Number of vehicles crossing the survey locations along the direction of measurement and in opposite direction was determined manually as per the standard format of IRC (Indian Roads Congress). Traffic composition in the study area included two wheelers, three wheelers, cars, jeeps, vans, buses, light commercial vehicles, and trucks.

\subsection{Spot speed measurement}

Spot speed measurements were made for each category of vehicles in the direction of survey using a handheld type radar speed measuring gun. Readouts from the digital display unit of the speed radar gun were recorded manually in the prescribed format. The highest possible number of spot speed measurements were made for each category of vehicles.

\subsection{Noise level}

Noise levels were measured in decibels using a Sound Level Meter (Lutron model SL-4010) which responds to sound in approximately same way as the human ear. Sound levels are displayed digitally. In order to lower the wind influence, a special sponge was placed on top of the microphone. Each day, this instrument was calibrated before taking measurements using a standard calibrator, all in accordance with the manufacturer's recommended procedure. The noise reading was recorded each time a vehicle passed by the noise meter. Noise levels were entered manually in an appropriate form. The highest possible number of noise readings were made for each category of vehicles. Many diverse data about selection of measurement location are available in literature. Therefore, the following precautions were taken to get accurate noise level readings:

1. Height of sound level meter above the road surface: 1,20 m.

2. Distance of operator from the sound level meter: 0,50 m.

3. Wind screen was used to eliminate wind effects.

4. Distance of sound level meter beyond the pavement edge: $1,50 \mathrm{~m}$.

5. The sound level meter was placed at the spot where there are no obstructions such as trees, high rise buildings, parked vehicles, etc. 
Table 2. Inter-correlation matrix

\begin{tabular}{|c|c|c|c|c|c|c|c|c|}
\hline Variables & Leq & $\mathrm{Q}$ & $P_{t}$ & $S_{t}$ & $\mathrm{~S}_{\mathrm{o}}$ & $\mathrm{T}_{\mathrm{a}}$ & $\mathrm{T}_{\mathrm{s}}$ & $\mathrm{H}$ \\
\hline Leq & 1 & $-0,30511$ & 0,376971 & 0,426739 & 0,607037 & $-0,4575$ & $-0,62876$ & 0,623723 \\
\hline Q & $-0,30511$ & 1 & 0,31317 & $-0,0999$ & $-0,32303$ & 0,594412 & 0,559956 & $-0,61668$ \\
\hline$P_{t}$ & 0,376971 & 0,31317 & 1 & 0,010799 & 0,02061 & 0,445622 & 0,296381 & $-0,33537$ \\
\hline$S_{t}$ & 0,426739 & $-0,0999$ & 0,010799 & 1 & 0,854109 & $-0,25162$ & $-0,35743$ & 0,328226 \\
\hline $\mathrm{S}_{\mathrm{o}}$ & 0,607037 & $-0,32303$ & 0,02061 & 0,854109 & 1 & $-0,39015$ & $-0,54079$ & 0,575244 \\
\hline $\mathrm{T}_{\mathrm{a}}$ & $-0,4575$ & 0,594412 & 0,445622 & $-0,25162$ & $-0,39015$ & 1 & 0,882062 & $-0,89493$ \\
\hline $\mathrm{T}_{\mathrm{s}}$ & $-0,62876$ & 0,559956 & 0,296381 & $-0,35743$ & $-0,54079$ & 0,882062 & 1 & $-0,92504$ \\
\hline $\mathrm{H}$ & 0,623723 & $-0,61668$ & $-0,33537$ & 0,328226 & 0,575244 & $-0,89493$ & $-0,92504$ & 1 \\
\hline
\end{tabular}

The equivalent noise level was computed using the standard formula and the survey data::

Leq $=10 * \log _{10}\left[10^{L 1 / 10}+10^{L 2 / 10}+10^{L 3 / 10}+\ldots . .+10^{\operatorname{Ln} / 10}\right] / n$

where, $L 1, L 2, L 3, \ldots . ., L n$ are individual noise level readings in $d B(A)$.

\subsection{Other parameters}

The surface temperature of the bituminous pavement was determined using a handheld laser thermometer. The digitally displayed reading was entered in the prescribed format. A table mounted digital thermo-hygrometer was used to measure the atmospheric temperature and relative humidity at the study locations. During each study period, the pavement surface temperature, atmospheric temperature, and relative humidity, were measured at the start and the end of survey, so as to obtain reliable average values.

\section{Mathematical formulation}

\subsection{Inter-correlation matrix of parameters}

Using the observed data, the correlation among the variables has been studied to find out the strength of association of dependent variables with independent variables, and among independent variables. The discussed correlation among variables is presented in Table 2.

\subsection{Model for prediction of an equivalent noise level}

Based on the data taken at different times and the equivalent level of noise, the analysis was done using the DATAFIT (Version 9) software, and a suitable model for the road traffic noise prediction in the four lane uninterrupted traffic flow condition was established. Equivalent level of noise in $d B(A)$,

Leq $=72.249-0.0058 \cdot \mathrm{Q}+0.2535 \cdot \mathrm{P}_{\mathrm{t}}+0.0606 \cdot \mathrm{S}_{\mathrm{t}}+0.0119 \cdot \mathrm{S}_{\mathrm{o}}+$ $0.0273 \cdot T_{a}-0.058 \cdot T_{s}+0.0638 \cdot H$
$\left(R^{2}=0.809\right)$

where:

Q - Total vehicle count in the direction of measurement,

$P_{t}$ - Percentage of two wheelers in the direction of measurement,

$\mathrm{S}_{t}$ - Average spot speed of two wheelers in the direction of measurement in $\mathrm{km} / \mathrm{h}$,

$\mathrm{S}_{\mathrm{o}}$ - Average spot speed of vehicles other than two wheelers in the direction of measurement in $\mathrm{km} / \mathrm{h}$,

$\mathrm{T}_{\mathrm{a}}$ - Average atmospheric temperature in ${ }^{\circ} \mathrm{C}$,

$\mathrm{T}_{\mathrm{s}}$ - Average pavement surface temperature in ${ }^{\circ} \mathrm{C}$,

$\mathrm{H}$ - Relative humidity in \%,

$\mathrm{R}^{2}$ - Coefficient of correlation.

In each and every kind of road the flow of two wheelers is a major influencing factor in traffic noise calculation. Hence, the percentage of two wheelers and the speed of two wheelers are specifically considered in this model.

\section{Results and discussion}

Based on the above formula, the equivalent level of noise developed in a four lane uninterrupted traffic flow condition was calculated. Values for Leq (Observed) and Leq (Calculated) for the selected locations are provided in Table 3.

The chi-square test for goodness of fit is used to determine the level of correspondence between the observed sample distribution and calculated distribution. The null hypothesis, $\mu=0$, meaning that the mean value of the differences between the pairs of observed noise and predicted noise is equal to zero, is considered. The calculated value of chi-square is less than the observed value at $5 \%$ level of significance. Hence, the null hypothesis is accepted and it is concluded that there is no significant difference between the observed and predicted noise levels. This model can therefore effectively be used in the prediction of highway traffic noise values in terms of Leq in India along four lane roads with uninterrupted traffic flow. Noise level values observed at four study locations are presented in Table 4. 
Table 3. Leq (observed) in regard to Leq (calculated)

\begin{tabular}{|c|c|c|c|}
\hline $\begin{array}{c}\text { Measure- } \\
\text { ment }\end{array}$ & $\begin{array}{l}\text { Leq (observed) } \\
{[d B(A)]}\end{array}$ & $\begin{array}{c}\text { Leq (calculated) } \\
{[d B(A)]}\end{array}$ & $\begin{array}{c}\text { Deviation } \\
{[\%]}\end{array}$ \\
\hline 1 & 84,02 & 83,685 & 0,399 \\
\hline 2 & 85,47 & 84,562 & 1,062 \\
\hline 3 & 82,81 & 84,604 & $-2,167$ \\
\hline 4 & 89,16 & 88,358 & 0,899 \\
\hline 5 & 83,10 & 84,003 & $-1,086$ \\
\hline 6 & 81,73 & 82,528 & $-0,977$ \\
\hline 7 & 83,27 & 83,195 & 0,090 \\
\hline 8 & 82,79 & 82,457 & 0,402 \\
\hline 9 & 81,24 & 81,925 & $-0,843$ \\
\hline 10 & 83,66 & 82,360 & 1,554 \\
\hline 11 & 80,63 & 81,579 & $-1,177$ \\
\hline 12 & 82,26 & 80,844 & 1,721 \\
\hline 13 & 80,30 & 81,224 & $-1,151$ \\
\hline 14 & 81,65 & 81,784 & $-0,164$ \\
\hline 15 & 81,54 & 80,597 & 1,156 \\
\hline 16 & 81,62 & 81,544 & 0,093 \\
\hline
\end{tabular}

This study shows that the average noise level at the above study locations in the four-lane uninterrupted traffic flow conditions amounts to $79.71 \mathrm{~dB}(\mathrm{~A})$ with the standard deviation of 5.20 $\mathrm{dB}(\mathrm{A})$, which exceeds the acceptable limit of $75 \mathrm{~dB}(\mathrm{~A})$ set by the Ministry of Environment and Forests (India) for industrial areas.

\subsection{Model validation}

Data were taken on another day at $\mathrm{km} 78 / 10$ of the above road ( $5^{\text {th }}$ location) following the same data collection procedure. The
Table 5. Observed and predicted equivalent noise levels in model validation

\begin{tabular}{|c|c|c|c|}
\hline S. No. & $\begin{array}{c}\text { Leq (observed) } \\
{[\mathrm{dB}(\mathrm{A})]}\end{array}$ & $\begin{array}{c}\text { Leq (calculated) } \\
{[\mathrm{dB}(\mathrm{A})]}\end{array}$ & $\begin{array}{c}\text { Deviation } \\
{[\%]}\end{array}$ \\
\hline 1 & 83,09 & 82,954 & 0,164 \\
\hline 2 & 82,59 & 83,367 & $-0,941$ \\
\hline 3 & 79,73 & 82,391 & $-3,338$ \\
\hline 4 & 81,25 & 81,532 & $-0,347$ \\
\hline 5 & 81,02 & 81,752 & $-0,903$ \\
\hline 6 & 81,64 & 81,517 & 0,151 \\
\hline 7 & 82,52 & 80,115 & 2,914 \\
\hline 8 & 80,98 & 78,886 & 2,586 \\
\hline 9 & 80,34 & 79,503 & 1,042 \\
\hline 10 & 81,11 & 79,149 & 2,418 \\
\hline 11 & 79,34 & 77,814 & 1,923 \\
\hline 12 & 79,99 & 78,425 & 1,956 \\
\hline 13 & 79,92 & 77,792 & 2,663 \\
\hline 14 & 80,66 & 78,971 & 2,094 \\
\hline
\end{tabular}

total of fourteen reading sets were taken at the $5^{\text {th }}$ location. The observed and predicted values of equivalent noise levels are compared in Table 5. Since predicted values deviate by less than $5 \%$, this model can be effectively used in the prediction of road traffic noise under conditions of uninterrupted traffic on four-lane roads in India.

\subsection{Influence of vehicle spot speed on noise level}

In most road vehicles, vehicle speed is an important factor in the noise level determination. The spot speed of vehicles surveyed at four study locations are presented in Table 6.

Table 4. Observed noise levels at study locations

\begin{tabular}{|c|c|c|c|c|}
\hline $\begin{array}{c}\text { Location (National } \\
\text { Highway NH 47) }\end{array}$ & $\begin{array}{c}\text { Minimal noise level } \\
{[\mathrm{dB}(\mathrm{A})]}\end{array}$ & $\begin{array}{c}\text { Maximal noise level } \\
{[\mathrm{dB}(\mathrm{A})]}\end{array}$ & $\begin{array}{c}\text { Mean noise level } \\
{[\mathrm{dB}(\mathrm{A})]}\end{array}$ & $\begin{array}{c}\text { Standard deviation of noise levels } \\
{[\mathrm{dB}(\mathrm{A})]}\end{array}$ \\
\hline $\mathrm{km} 82 / 2$ & 69,60 & 105,20 & 81,48 & 5,26 \\
\hline $\mathrm{km} \mathrm{73/10}$ & 64,50 & 94,40 & 80,18 & 5,18 \\
\hline $\mathrm{km} 68 / 8$ & 62,60 & 96,90 & 79,23 & 5,16 \\
\hline km 60/10 & 65,90 & 96,40 & 78,57 & 4,84 \\
\hline
\end{tabular}

Table 6. Spot speed of vehicles at study locations

\begin{tabular}{|c|c|c|c|c|}
\hline \multirow{2}{*}{$\begin{array}{c}\text { Location (National } \\
\text { Highway NH 47) }\end{array}$} & Minimal [km/h] & Maximal $[\mathrm{km} / \mathrm{h}]$ & Mean $[\mathrm{km} / \mathrm{h}]$ & Standard deviation $[\mathrm{km} / \mathrm{h}]$ \\
\cline { 2 - 5 } & 20,00 & 141,00 & 68,56 & 22,77 \\
\hline $\mathrm{km} \mathrm{82/2}$ & 21,00 & 130,00 & 57,76 & 19,21 \\
\hline $\mathrm{km} \mathrm{73/10}$ & 19,00 & 127,00 & 60,80 & 17,69 \\
\hline $\mathrm{km} \mathrm{68/8}$ & 13,00 & 128,00 & 56,11 & 20,18 \\
\hline $\mathrm{km} \mathrm{60/10}$ & & & \\
\hline
\end{tabular}


In the study locations, the average vehicle speed was $60.07 \mathrm{~km} / \mathrm{h}$, with the standard deviation of $20.21 \mathrm{~km} / \mathrm{h}$. A formula for predicting the equivalent noise emitted by each category of vehicles based on its spot speed was defined. It is presented in Table 7 where $\mathrm{S}$ denotes the vehicle spot speed in $\mathrm{km} / \mathrm{h}$.

In all equations given in Table 7, the nature of the second term is positive. This implies that in all categories of vehicles the increase in spot speed results in an appropriate increase in the equivalent noise level.

Table 7. Equations showing individual vehicle noise for different vehicle categories

\begin{tabular}{|l|c|}
\hline Category of vehicle & $\begin{array}{c}\text { Individual vehicle noise } \\
\text { emission equation* }\end{array}$ \\
\hline Two wheelers & Leq $=73,29+0,040 \cdot \mathrm{S}$ \\
\hline Three wheelers / Auto & Leq $=72,80+0,082 \cdot \mathrm{S}$ \\
\hline Car, Jeep \& Tempo & Leq $=73,01+0,095 \cdot \mathrm{S}$ \\
\hline Bus & Leq $=76,50+0,101 \cdot \mathrm{S}$ \\
\hline Lorry & Leq $=78,37+0,109 \cdot \mathrm{S}$ \\
\hline Trailers \& Containers & Leq $=76,58+0,184 \cdot \mathrm{S}$ \\
\hline $\begin{array}{l}\text { Leq - equivalent noise level in } \mathrm{dB}(\mathrm{A}) ; \\
\text { S- vehicle spot speed in } \mathrm{km} / \mathrm{h}\end{array}$ \\
\hline
\end{tabular}

\subsection{Scatter plots}

Scatter plots of $P_{t}$ Vs Leq, $S_{t}$ Vs Leq, $S_{0}$ Vs Leq, $T_{a}$ Vs Leq, $T_{s}$ Vs Leq, H Vs Leq and Q vs Leq are plotted to investigate a possible relationship between individual parameters on an equivalent level of noise. These plots are shown in Figures 2 to 8.

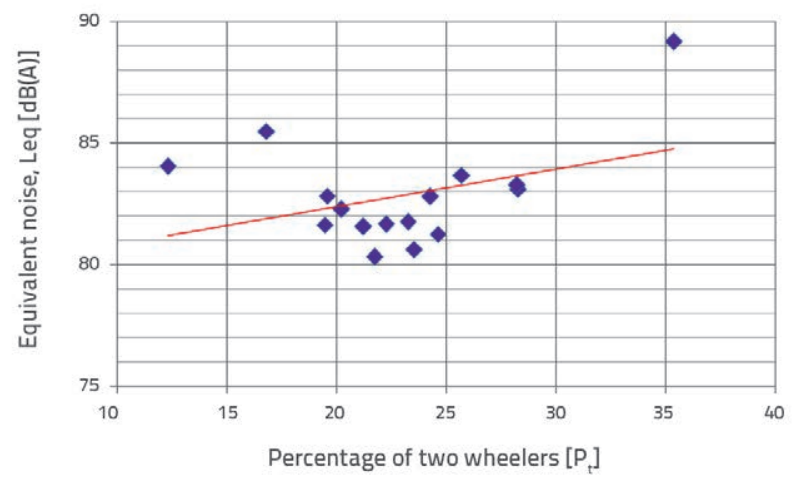

Figure 2. Percentage of two wheelers $\left(\mathrm{P}_{\mathrm{t}}\right)$ in regard to equivalent noise level (Leq)

Figure 2 shows that the equivalent noise level increases with an increase in the percentage of two wheelers. Hence, it is proven that the flow of two wheelers increases the equivalent noise level, not only on undivided highways, but also on divided four lane highways.

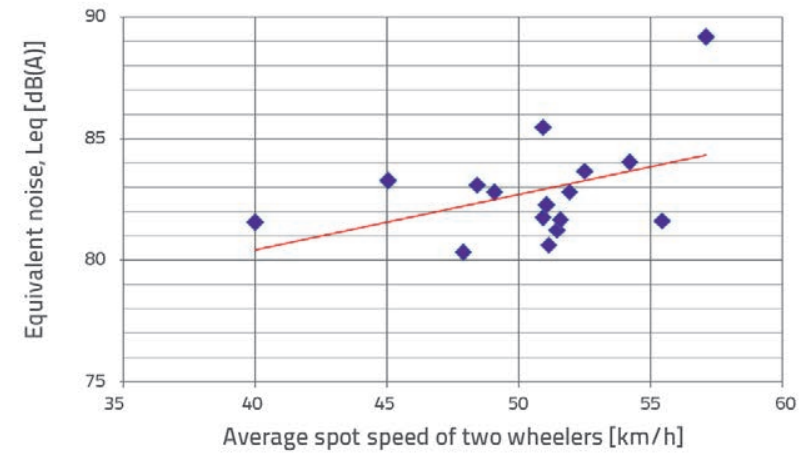

Figure 3. Average spot speed of two wheelers $\left(S_{t}\right)$ in regard to equivalent noise level (Leq)

Figure 3 depicts the relationship between an average spot speed of two wheelers and the equivalent noise level, where the equivalent noise level increases with an increase in the average spot speed of two wheelers. Hence it is proven that, in addition to the number of two wheelers, their spot speed also contributes to an increase in the equivalent noise level.

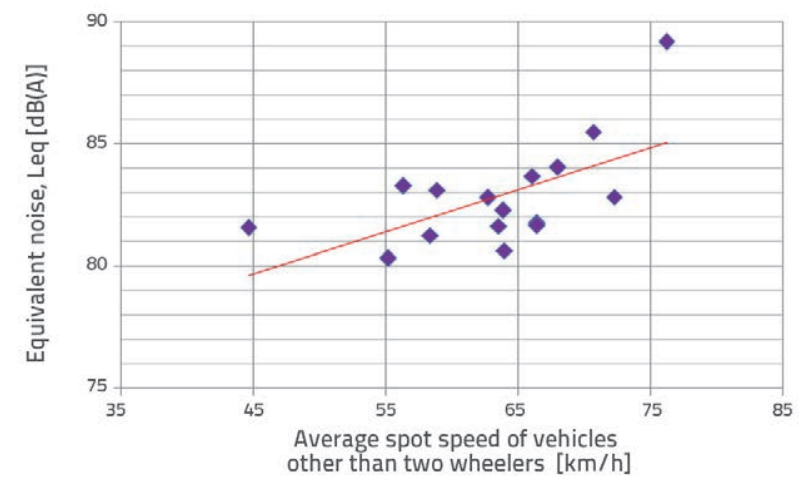

Figure 4. Average spot speed of vehicles other than two wheelers $\left(\mathrm{S}_{0}\right)$ in regard to equivalent noise level (Leq)

Figure 4 shows that the equivalent noise level increases with an increase in the average spot speed of vehicles other than two wheelers. Thus, the increase in spot speed of all kinds of vehicles increases the equivalent noise level.

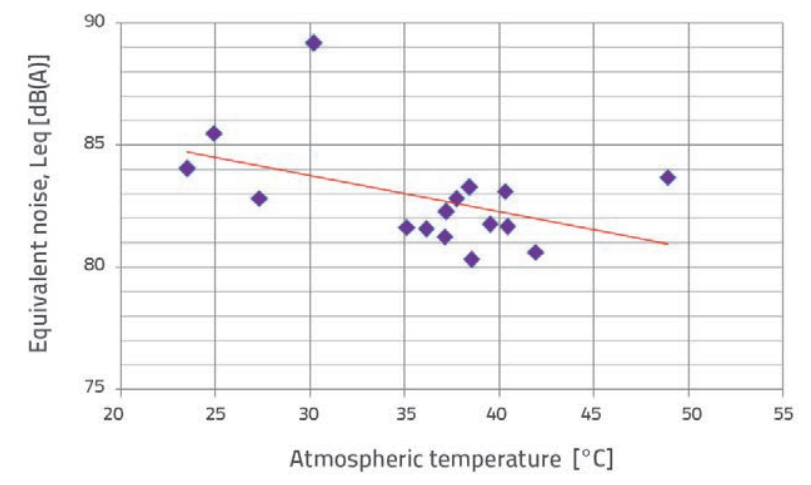

Figure 5. Atmospheric temperature $\left(\mathrm{T}_{\mathrm{a}}\right)$ in regard to equivalent noise level (Leq) 
Figure 5 shows the variation of equivalent noise with atmospheric temperature. It can be seen that an increase in atmospheric temperature decreases the level of noise.

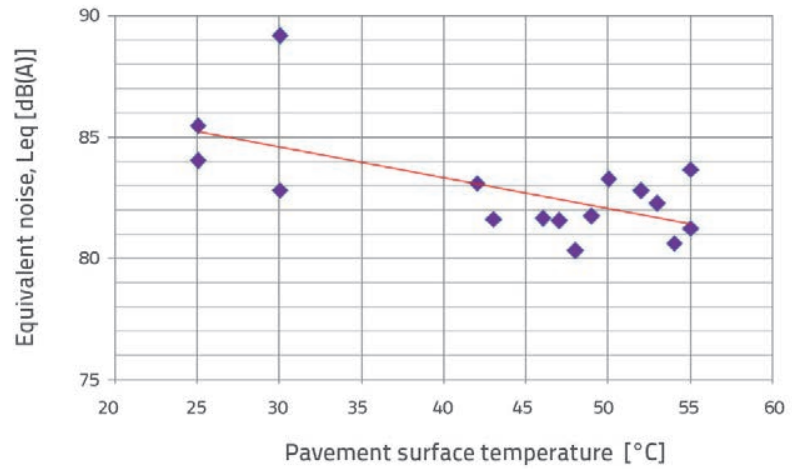

Figure 6. Pavement surface temperature $\left(\mathrm{T}_{\mathrm{s}}\right)$ in regard to equivalent noise level (Leq)

Figure 6 gives an idea about the variation of equivalent noise with the change in pavement surface temperature. The equivalent noise is high at lower pavement surface temperatures. However, an increase in pavement surface temperature leads to reduced noise. At lower pavement temperatures, the pavement surface has a higher moisture content at which the interaction with vehicle tyre surface generates more noise. It can therefore be observed that an increase in pavement surface temperature decreases the equivalent noise level.

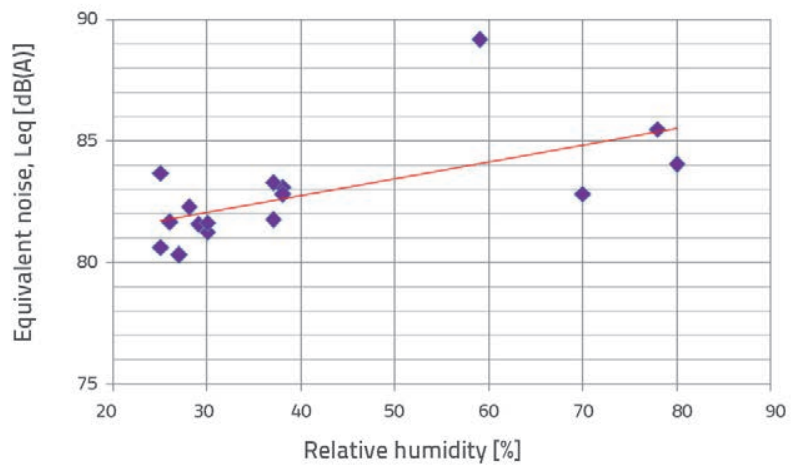

Figure 7. Relative humidity $(\mathrm{H})$ in regard to equivalent noise level (Leq)

The relationship between relative humidity and equivalent noise level is shown in Figure 7. It can be observed that the equivalent noise level increases with an increase in relative humidity. The increase in relative humidity increases the moisture content of atmospheric particles and the pavement surface, which results in a higher equivalent noise level.

The distribution of the equivalent noise level with the total number of vehicles is shown in Figure 8 . It is evident that the noise level increases with the number of vehicles. But, in the above plot, the equivalent noise level decreases with an increase in the total number of vehicles. The sound level readings were recorded when a vehicle crosses the sound level meter. For example, if a two wheeler, a car, and a truck are passing simultaneously, then the maximum noise level produced at that instant was recorded for the major type of vehicle. At this juncture, it is impossible to find out the contribution of noise level by each type of vehicles. However, the total numbers of vehicles passing by the place are counted. Hence this form of difference occurs, and it implies that the number of overtaking vehicles is greater at the selected locations. This difference may be nullified if the vehicles cross piecemeal which is virtually unfeasible on a divided four lane highway.

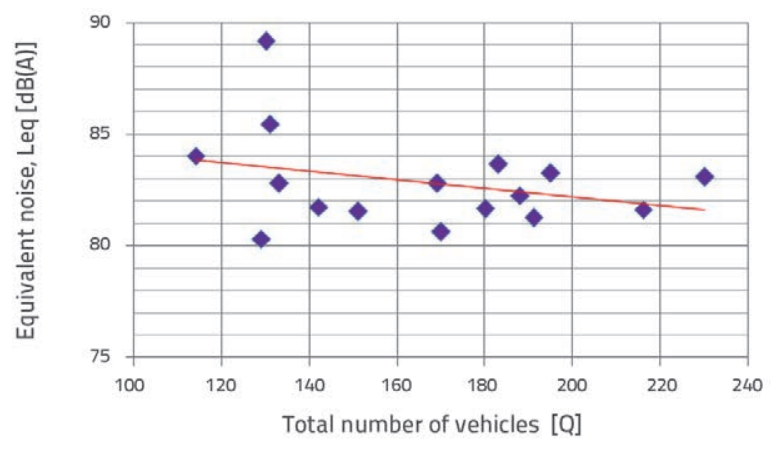

Figure 8. Total number of vehicles (Q) in regard to equivalent noise level (Leq)

During the measurement, another interesting factor was observed: the level of noise produced by two wheelers, especially mopeds like TVS50, was greater than $80 \mathrm{~dB}(\mathrm{~A})$. Here the increased noise is generated by the silencer. In India, mopeds like TVS 50 are designed to carry great loads at high speed. Their design to accommodate more load and swift pickup leads to modified silencers that generate more noise. In most cases, noise levels produced by such mopeds are much higher than noise levels generated by modern cars and even by multi-axle buses.

\section{Conclusion}

Based on the data collected from four-lane uninterrupted traffic flow condition, a model for predicting the level of equivalent noise was generated using the DATAFIT software. Its goodness of fit was also examined to establish the level of its suitability. The following conclusions were made on the basis of this study:

- The multiple linear regression equation for predicting the equivalent noise level (Leq) was established using the following parameters: the total number of vehicles (Q), percentage of two wheelers $\left(P_{t}\right)$, spot speed of two wheelers $\left(S_{t}\right)$, spot speed of other vehicles $\left(S_{0}\right)$, atmospheric temperature $\left(\mathrm{T}_{\mathrm{a}}\right)$, pavement surface temperature $\left(\mathrm{T}_{\mathrm{s}}\right)$, and relative humidity $(\mathrm{H})$. Percentage errors between observed and predicted volumes were negligible.

- The $R^{2}$ value for this equation was found to be 0.809 . The $R^{2}$ value can be improved by incorporating variations, i.e. by taking more data sets at a number of different locations and at different time intervals. 
- While testing the goodness of the equation, the null hypothesis, $\mu=0$, i.e. the case when the mean value of differences between the pairs of observed noise and predicted noise is equal to zero, was considered. Results of the Chi-square test at the five percentage level of significance shows that the null hypothesis is acceptable, i.e. that the mean value of the difference between the observed and predicted noise levels is zero.

- The predicted model exhibited a very low percentage of error for the test data (i.e. for the data taken at the $5^{\text {th }}$ location). Hence the model can be used for predicting noise level at similar roads in India.

\section{REFERENCES}

[1] Ozer, S.; Yilmaz, H.; Yesil, M., Yesil, P.: Evaluation of noise pollution caused by vehicles in the city of Tokat, Turkey, Scientific Research and Essay, 4 (2009), pp. 1205-1212.

[2] Gundogdu, O., Gokdag, M., Yuksel, F.: A traffic noise prediction method based on vehicle composition using genetic algorithms, Applied Acoustics 6 (2005), pp. 799-809.

[3] Yilmaz, G., Hocanli, Y.: Mapping of Noise by using GIS in Sanliurfa, Environmental Monitoring and Assessment 121 (2006), pp. 103108.
- The scatter plots of $P_{t}$ - Leq (percentage of two wheelers in the direction of measurement and equivalent noise level), $S_{t}$ - Leq (average spot speed of two wheelers in the direction of measurement and equivalent noise level), $\mathrm{S}_{0}$ Leq (verage spot speed of vehicles other than two wheelers in the direction of measurement and equivalent noise level), $\mathrm{T}_{\mathrm{a}}$ - Leq (average atmospheric temperature and equivalent noise level), $T_{s}$ - Leq (average pavement surface temperature and equivalent noise level), $\mathrm{H}$ - Leq (relative humidity and equivalent noise level), and Q - Leq (coefficient of correlation and equivalent noise level) were plotted, and the influence of this parameter on the level of noise was studied.

[4] Pamanikabud, P.; Tansatcha, M., Brown, A.L.: Development of a highway noise prediction model using an Leq 20 s measure of basic vehicular noise, Journal of Sound and Vibration 316 (2008), pp. 317-330.

[5] Alam, J.B., Rahman, M.M., Dikshit, A.K., Khan, S.K.: Study of traffic noise level of Sylhet by multiple regression analysis associated with health hazards, Iran Journal of Environmental Health Science Engineering 3 (2006), pp. 71-78.

[6] Alam, M.D., Rauf, A.F.M.A., Ahmed, M.F.: Traffic induced noise pollution in Dhaka city. Journal of Civil Engineering, The Institution of Engineers, Bangladesh 29 (2001), pp. 55-63. 